\title{
RELATIONSHIP OF FERMENTATION TIME TO THE CUT TEST AND ANTHOCYANIN CONTENT IN COCOA (THEOBROMA CACAO)
}

\author{
D. D. ABEYGUNASEKERA AND E. R. JANSZ \\ Ceylon Institute of Scientific and Industrial Research (CISIR), P.O. Box 787, \\ 363, Bauddbaloka Mawatha, Colombo 7, Sri Lanka.
}

(Daie of receipt: 04 August 1988)

(Date of acceptance: O9 Jänuary 1989)

\begin{abstract}
Cocoa collected from Wariyapola Estate, Matale, was fermented by the basket method. It was found that the "cus cest" can be applied to determine fermentation times of lipto two days provided the batch is a mixture of the criollo and forestero varieties. Although anthocyanin content declined by nearly $70 \%$ within six days fermentation this parameter cannot be generally used to determine fermentation time.
\end{abstract}

\section{Introduction}

Fermentation, which is an important step in the processing of cocoa in Sri Lanka has received insufficient attention in the past and the process is largely uncontrolled. The duration of fermentation is a crucial aspect of primary processing of raw cocoa as it results in the formation of precursors of essential aroma compounds while bringing about a decline of astringency and bitterness. Therefore it is essential that cocoa beans are fermented for an. optimum period in order to produce an acceptable flavour.

Fermentation trials on Sri Lankan cocoa have been reported by Ogutuga $^{4}$ who monitored $\mathrm{pH}$ changes and temperature variation of the fermenting cocoa. However, this study does not report $\approx$ specific period for fermentation and highlighted the tray method of fermentation for mixed varieties of beans.

The present study was conducted on cocoa beans obtained from Wariyapola Estate, Matale, Sri Lanka, where there is a mixed variety of forestero and criollo beans. While it is known criollo beans generally require 2-3 days of fermentation ${ }^{10}$ and forestero beans $5-7$ days, optimum fermentation time would also depend on the method of fermentation adopted.

Of the several methods of fermentation ${ }^{+}$available the basket method was used during this study as the target group of processors were the smallnolders. It is also noted that at the present time most smallholders limit fermentation time to $-1 \frac{1}{2}$ days.

Raw material from the estate selected was subject to a basic study on selected fermentation parameters after which an attempt was made to correlate fermentation and storage time with the cut test and anthocyanin content with a view to aiding in the grading of cocoa. This study is considered important as the present practice ${ }^{9}$ of grading cocoa on external appearance is considered undesirable. 


\section{Experimental}

\subsection{Plant Material}

Mature pods of Theobroma cacao were collected from different divisions of Wariyapola Estate, Matale, Sri Lanka, pooled and a representive sample drawn. These pods were a mixture of the criollo and forestero varieties in the ratio of approximately $7: 3$.

\subsection{Fermentation}

\subsubsection{Method}

The basket fermentation technique ${ }^{4}$ was employed. Total fermentation time was 6 days and samples were drawn daily. The beans were turned after $48 \mathrm{~h}$ fermentation. Fermented cocoa beans thus produced were sun-dried for 3 days after spreading on coir matting.

\subsubsection{Routine Measurements}

The following parameters were measured throughout fermentation:-

(i) $\mathrm{pH}$ of water extract of beans and pulp ${ }^{6}$

(ii) Temperature

(iii) Acetic acid content ${ }^{7}$

(iv) Reducing and total sugar content ${ }^{1,8}$

(v) Fat content (by Soxhlet extraction with diethyl ether)

\subsection{Storage}

Cocoa beans $(2 \mathrm{~kg}$ ) were stored in small jute--hessian (gunny) bags upto three months.

\subsection{Cut Test}

The cut test was performed by cutting the cocoa beans (of varying fermentation and storage time) lengthwise and counting the number of lilac, cinnamon-brown, purple, purple-brown and brown beans which are easily distinguishable to the naked eye (modified from method of Wood ${ }^{10}$ ). Approximately $1 \mathrm{~kg}$. of cocoa beans was used for each experimental point.

\subsection{Assay of Arthocyanin}

Anthocyanins were extracted and assayed by two methods - that of Pettipher $^{5}$ and Lees and Francis ${ }^{2}$ where absorbance is measured and converted to anthocyanin content by formulae given in the respective methods. 


\subsubsection{Method of Pettipher}

Cocoa beans $(100 \mathrm{~g})$ were deshelled and blended in $1 \% \mathrm{v} / \mathrm{v} \mathrm{HCl}$ (1 litre) using a Waring blender. The suspension was allowed to stand for 5 min. An aliquot $(10 \mathrm{ml})$ was centrifuged for $10 \mathrm{~min}$.

A Sep Pak C18 cartridge (Waters Associates, London) was prepared for extraction by passing methanol $(2 \mathrm{ml})$ followed by $(1 \% \mathrm{v} / \mathrm{v}) \mathrm{HCl}(5 \mathrm{ml})$ through the cartridge using a plastic syringe.

The supernatant $(2 \mathrm{ml})$ of the acid extract was passed through the cartridge and the eluent discarded. The cartridge was then rinsed by passing through $1 \% \mathrm{v} / \mathrm{v} \mathrm{HCl}(4 \mathrm{ml})$ and the eluent discarded. Air was passed through the cartridge to expel any remaining liquid.

The anthocyanins were eluted from the cartridge by passing through $50 \%(\mathrm{v} / \mathrm{v})$ methanol $(4.5 \mathrm{ml})$, followed by air, collecting the total eluent. The absorbance of the eluent was measured at $520 \mathrm{~nm}$ using a Perkin Elmer model 552 spectrophotometer.

\subsubsection{Method Lees and Francis}

Dried geshelled cocoa beans $(100 \mathrm{~g})$ were blended $0.1 \mathrm{~N} \mathrm{HCl}$ in ethanol, 15:85 (1 litre). The macerate was stored overnight at $4^{\circ} \mathrm{C}$ in a stoppered flask.

An aliquot $(10 \mathrm{ml})$ was removed and centrifuged. The absorbance of the supernatant was measured at $535 \mathrm{~nm}$ using a Perkin Elmer model 552 spectrophotometer.

\section{Results}

\subsection{Preliminary Results}

As expected the $\mathrm{pH}$ of cocoa bean pulp increased (from 3.2) and finally stabilized at about 4.5 and that of the bean decreased from $\mathrm{pH} 6.0$ to 4.7 in $5-6$ days. A final acetic acid content of $0.7 \% \mathrm{w} / \mathrm{v}$ was attained in the bean after 6 days of fermentation. A maximum temperature $\left(41-42^{\circ} \mathrm{C}\right)$ of the fermenting mass was attained around $4-5$ days after fermentation began this was followed by a decline in temperature to $38^{\circ} \mathrm{C}$ on the sixth day.

Total sugar content declined by about $15 \%$ during 6 days fermentation to $1.7 \% \mathrm{w} / \mathrm{w}$. While initially approximately $50 \%$ of the sugar was nonreducing at the end of 6 days fermentation approximately $95 \%$ of the sugar was reducing in nature. Cocoa fat content remained relatively steady between 40 and $44 \% \mathrm{w} / \mathrm{w}$ upto six days fermentation. 


\subsection{Effect of Fermentation Time}

\subsubsection{Cut Test}

Results of the cut test are shown in Table 1. There was a tendency for the criollo bean to turn from lilac to cinnamon-brown and the forestero bean from purple to brown with fermentation.

Table 1. The cut test with varying fermentation time

\begin{tabular}{cccccc}
\hline \multirow{2}{*}{ Fermentation Time } & \multicolumn{5}{c}{ Cotyledons (Number) } \\
\cline { 2 - 6 } (days) & Lilac & $\begin{array}{c}\text { Cinnamon } \\
\text { Brown }\end{array}$ & Purple & Purple/Brown & Brown \\
\hline 0 & $15-20$ & $0-5$ & $65-70$ & $0-5$ & - \\
1 & $5-10$ & $10-15$ & $45-50$ & $25-30$ & $10-15$ \\
2 & $<5$ & $15-20$ & $40-45$ & $30-35$ & $15-20$ \\
3 & - & $15-20$ & $20-25$ & $30-35$ & $25-30$ \\
4 & - & $15-20$ & $10-15$ & $15-20$ & $35-40$ \\
5 & - & $15-20$ & $<5$ & $10-15$ & $50-55$ \\
6 & - & $15-20$ & - & $<5$ & $>65$ \\
\hline
\end{tabular}




\subsubsection{Anthocyanin Content}

Anthocyanin levels paralleled the results of the cut test (Table 2).

Table 2. Anthocyanin content of fermented cocoa beans

\begin{tabular}{ccc}
\hline Fermentation Time & \multicolumn{1}{c}{ Anthocyanins (\%) } \\
\cline { 2 - 3 } (days) & A & B \\
\hline 0 & 100 & 1.00 \\
1 & 92.4 & 91.7 \\
2 & 72.0 & 71.4 \\
3 & 62.5 & 62.4 \\
4 & 50.2 & 49.6 \\
5 & 35.5 & 35.3 \\
6 & 31.2 & 31.5 \\
\hline
\end{tabular}

Moisture $6-8 \%$

Duration of drying -3 days (sun drying)
A - Method of Pettipher 5
B - Method of Lees and Francis 4

$100 \%$ anthocyanin represents approximately $13.3 \mu$ moles per $100 \mathrm{~g}$ cocoa 


\subsection{Effect of Storage}

Results of the cut test are shown in Table 3 and the corresponding results of anthocyanin assays are shown in Table 4.

Table 3. Variation of storage time on the "cut" test

\begin{tabular}{|c|c|c|c|c|c|c|}
\hline \multirow{2}{*}{$\begin{array}{l}\text { Storage Period } \\
\text { (months) }\end{array}$} & \multirow{2}{*}{$\begin{array}{c}\text { Fermentation } \\
\text { Time } \\
\text { (days) }\end{array}$} & \multicolumn{5}{|c|}{ Cotyledons (Number) } \\
\hline & & Lilac & $\begin{array}{c}\text { Cinnamon } \\
\text { brown }\end{array}$ & Purple & $\begin{array}{l}\text { Purple } \\
\text { brown }\end{array}$ & Brown \\
\hline \multirow[t]{5}{*}{0} & 0 & $15-20$ & $0-5$ & $65-70$ & $0-5$ & 0 \\
\hline & 1 & $5-10$ & $10-15$ & $45-50$ & $25-30$ & $10-15$ \\
\hline & 2 & $<5$ & $15-20$ & $40-45$ & $30-35$ & $15-20$ \\
\hline & 3 & 0 & $15-20$ & $20-25$ & $30-35$ & $25-30$ \\
\hline & 4 & 0 & $15-20$ & $10-15$ & $15-20$ & $35-40$ \\
\hline \multirow[t]{5}{*}{1} & 0 & $15-20$ & $0-5$ & $65-70$ & $5-10$ & 0 \\
\hline & 1 & $5-10$ & $10-15$ & $45-50$ & $25-30$ & $10-15$ \\
\hline & 2 & $<5$ & $15-20$ & $25-30$ & $35-40$ & $15-20$ \\
\hline & 3 & 0 & $15-20$ & $10-15$ & $35-40$ & $25-30$ \\
\hline & 4 & 0 & $15-20$ & $5-10$ & $20-25$ & $35-40$ \\
\hline \multirow[t]{5}{*}{2} & 0 & $15-20$ & $0-5$ & $65-70$ & $5-10$ & 0 \\
\hline & 1 & $5-10$ & $10-15$ & $45-50$ & $25-30$ & $10-15$ \\
\hline & 2 & $<5$ & $15-20$ & $25-30$ & $35-40$ & $15-20$ \\
\hline & 3 & 0 & $15-20$ & $10-15$ & $35-40$ & $25-30$ \\
\hline & 4 & 0 & $15-20$ & $5-10$ & $20-25$ & $35-40$ \\
\hline \multirow[t]{5}{*}{3} & 0 & $15-20$ & $0-5$ & $65-70$ & $10-15$ & $0^{-}$ \\
\hline & 1 & $5-10$ & $10-15$ & $40-45$ & $30-35$ & $10-15$ \\
\hline & 2 & $<5$ & $15-20$ & $20-25$ & $35-40$ & $25-30$ \\
\hline & 3 & 0 & $15-20$ & $10-15$ & $35-40$ & $30-35$ \\
\hline & 4 & 0 & $15-20$ & $5-10$ & $20-25$ & $35-40$ \\
\hline
\end{tabular}


Table 4. Assay of cocoa bean during three months of storage for anthocynin content

\begin{tabular}{ccccc}
\hline Fermentation Time & \multicolumn{4}{c}{ Storage (Months) } \\
& 0 & 1 & 2 & 3 \\
\hline (days) & 100 & 92.2 & 90.9 & 90.6 \\
\hline 0 & 92.0 & 88.6 & 88.6 & 87.5 \\
1 & 79.5 & 74.2 & 68.2 & 68.0 \\
2 & 72.9 & 70.6 & 67.0 & 66.7 \\
3 & 68.9 & 68.2 & 66.3 & 64.3 \\
4 & & & Anthocyanins $(\%)$ & \\
\hline
\end{tabular}

Absorbarice was measured by the Method of Pettipher ${ }^{5}$

$100 \%$ anthocyanins represent approximately $19.5 \mu$ moles

anthocyanins per $100 \mathrm{~g}$ cocoa

\section{Discussion}

The study defined the basic fermentation characteristics of mixed Sri Lankan criollo and forestero cocoa when fermented by the basket method.

Although the acidity of the fermented cocoa bean is low it is not as low as that reported by Liau in Malaysia. ${ }^{3}$

The study revealed that fermentation time can be determined by the cut test soon after fermentation provided the plantation is a mixed forestero and criollo. The more complicated anthocyanin test is of less use especially as initial anthocyanin content may not be known.

Storage of beans results in a complex situation but still using the criollo beans one can distinguish between 0,1 and 2 days fermentation. The cut test is of less use at 3 or 4 days fermentation as for example, 3 day fermented beans after three months are difficult to distinguish from a more fermented bean stored for a lesser time.

The anthocyanin test is of still less use as it does not have the advantage of evaluating the criollo and forestero beans separately. Further it does not monitor the development of the brown pigment.

As cocoa beans in Sri Lanka are almost never fermented beyond 2 days, the cut test has considerable value provided there is a significant proportion of criollo beans in the particular batch of cocoa. 


\section{Acknowledgements}

The authors thank S. J. Sarath Kumara and E. V. Packiyasothy for discussions and other assistance and Mrs. I. Bandara for secretarial assistance.

\section{References}

1. HAROLD, E., KIRK, R. S. \& SWAYER, S. (1981) Pearsons Chemical Analysis of Food Churchill Livingston. Edinburgh 150 .

2. LEES, D. H. \& FRANCIS F. J. (1971)-J. Food Sci., $36: 1056$

3. LIAU, T. L. (1976) Proc. East. Malaysian Plantation Association Cocoa - Coconut Seminar.

4. OGUTUGA, D. B. A. (1976) Cocoa Processing in Sri Lanka UNDP/FAO Project on Research and Experimentation on Minor.Export Crops, Sri Lanka.

5. PETTIPHER, G. (1956) J. Sci. Food Agric., $37: 289$

6. ROHAN, T. A. (1958) J. Sci. Food Agric., $9: 104$

7. ROHAN. T. A. \& STEWART, (1964) Rev. Interm. Cboc., $19: 502$

8. ROHAN, T. A. \& STEWART, T. (1966) J. Food Sci., $31: 207$

9. SRI LANKA STANDARD (1977) The Standard Specification of Cocoa SLS 106. Bureau of Ceylon Standards

10. WOoD, G. A. R. (1975) Cocoa 3rd ed. Longman, London. 